\title{
Evaluating land subsidence by field survey and D-InSAR technique in Damaneh City, Iran
}

\author{
Akbar GHAZIFARD $^{1 *}$, Elham AKBARI ${ }^{1}$, Koroush SHIRANI ${ }^{2}$, Homayon SAFAEI $^{1}$ \\ ${ }^{1}$ Department of Geology, Faculty of Science, University of Isfahan, Isfahan 81746-73441, Iran; \\ ${ }^{2}$ Department of Soil Conservation and Watershed Management, Isfahan Agricultural and Natural Resources Research and \\ Education Center, Isfahan 81748-35118, Iran
}

\begin{abstract}
Based on the data from piezometers, well logs, geophysical surveys and the interferometric synthetic aperture radar (InSAR) technique, this study investigates the main causes of land subsidence in Damaneh City, Iran. The size, openings and direction of fissures were measured by micrometer and compass. The locations of fissures and wall cracks were determined by GPS. The geoelectrical data were used to determine the composition, thickness, depth and shape of lower parts of the aquifer. Groundwater fluctuations were evaluated by available piezometers. The InSAR technique was used to measure land deformation from space and to map the dense changes of surface displacements. The results indicate that the main cause of ground subsidence is the decline of groundwater heads and changes in composition and thickness of compressible lacustrine sediments. The subsidence map obtained from the radar data of ASAR sensor of ENVISAT satellite shows that the subsidence zone is mainly in northern city that is underlain by very thick fine sediments. The subsidence rates from March to December 2005 and from July 2011 to January 2012 are 6.7 and $7.0 \mathrm{~cm} / \mathrm{a}$, respectively. The results also show good correlations among the formation of earth features, decline in groundwater head and thickness of fine-grained sediments. We recommend that the groundwater withdrawal for agricultural and industrial sectors should be restricted and urban expansion in the northern part of the city should be constrained.
\end{abstract}

Keywords: land subsidence; water withdrawal; D-interferometric synthetic aperture radar; Damaneh City

Citation: Akbar GHAZIFARD, Elham AKBARI, Koroush SHIRANI, Homayon SAFAEI. 2017. Evaluation of land subsidence by field survey and D-InSAR technique in Damaneh City, Iran. Journal of Arid Land, 9(5): 778-789. doi: $10.1007 / \mathrm{s} 40333-017-0104-5$

\section{Introduction}

Land subsidence is either a gradual settling or a sudden sinking of earth surface accompanied with some horizontal displacements (Bates and Jackson, 1980). The natural occurrence of this phenomenon is usually resulted from such geological processes as solubility, thawing of ice, vibration and densification of deposits. A major man-made occurrence of subsidence in the world is the withdrawal of fluids from subsurface (Bell, 1999; Adiyaman, 2012). Ground subsidence unfortunately can result in irreparable damages to water resources, infrastructures, agricultures, industries, and residences. Ground subsidence can also cause changes in the direction and velocity of groundwater flow (Holzer and Galloway, 2005).

According to Galloway et al. (1999), groundwater withdrawal is the most common cause of subsidence. Groundwater withdrawal from aquifers for a long period of time can decrease pore

\footnotetext{
*Corresponding author: Akbar GHAZIFARD (E-mail: ghazifard@yahoo.com; a.ghazifard@sci.ui.ac.ir)

Received 2017-02-05; revised 2017-05-14; accepted 2017-08-08

CC Xinjiang Institute of Ecology and Geography, Chinese Academy of Sciences, Science Press and Springer-Verlag GmbH Germany 2017
} 
water pressure and increase effective stress (Burbey, 2002). As effective stress increases, permeability and thickness of sediments decrease, and density and weight of sediments increase, leading to permanent changes in soil grain configuration and volume. This process continues even after groundwater withdrawal stops (Adiyaman, 2012).

Subsidence phenomenon is reported to have affected many major cities such as Mexico City of Mexico (Ortega-Guerrero et al., 1999), Taipei of China (Hou et al., 2005), Bangkok of Thailand (Phien-Wej et al., 2006), Osaka and Tokyo of Japan, Arizona of USA (Wei, 2006), Venice of Italy, Jakarta of Indonesia, Kolkata of India (Chatterjee et al., 2006), Kerman of Iran (Sharifikia, 2009; Esmaili and Motagh, 2009), Shanghai and Beijing of China (Wang et al., 2009) and Kashan of Iran (Ghazifard et al., 2016). The ground subsidence phenomenon in Iran is mostly due to excessive groundwater withdrawal, high sediment thickness, low bearing capacity of sediments and solution of subsurface formations (Ghazifard et al., 2016).

It is highly desired to create a suitable system to monitor the subsidence phenomenon. Methods such as GPS (Sneed and Galloway, 2000; Bell et al., 2002), leveling (Bell and Price, 1991; Bell et al., 2002), optical remote sensing, air photo, extensometer and boreholes (Pope and Burbay, 2004; Carruth et al., 2007) have been used to measure the amount of deformation and displacement of ground surface. Advanced GPS and radar detectors are usually used to infer the information associated with ground subsidence (Galloway et al., 2000). In recent years, synthetic aperture radar interferometry has been used to measure vertical displacement with time (Hoffmann et al., 2001; Bell et al., 2002; Rosen et al., 2004; Galloway and Burbey, 2011). In this method, a series of microwave pulses are sent from satellite toward the earth surface and the satellite receives the reflected waves. The obtained interferogram of phase differences can be used to estimate the vertical displacements of earth surface (Massonnet and Feigl, 1998; Galloway and Hoffmann, 2007). This radar technique can be used in any different climate conditions and verified by GPS and leveling data.

This study deals with the land subsidence in the east and northeast parts of the Damaneh City of Iran where excessive groundwater withdrawal and declines of groundwater head have been undergone for years due to increasing population and intensifying agricultural activities, causing ground subsidence. The subsidence-generated earth fissures and rupture of houses and roads and uplifting of well casings were observed for the first time in 2013.

\section{Study area}

Damaneh City $\left(33^{\circ} 00^{\prime} 20^{\prime \prime}-33^{\circ} 011^{\prime} 32^{\prime \prime} \mathrm{N}, 50^{\circ} 28^{\prime} 43^{\prime \prime}-50^{\circ} 29^{\prime} 58^{\prime \prime} \mathrm{E}\right)$ is located in a semi-arid area on the west side of Isfahan Province in Central Iran. The city covers an area of $2 \mathrm{~km}^{2}$ and is surrounded by Gahiz swamp, Darehbid and Ashjerd farmlands (Fig. 1). The altitude of Damaneh City is between $2330-2370 \mathrm{~m}$ a.s.l. and the average slope is about $5 \%$ toward north. Gahiz swamp, on the east side of the city, was filled with water about 50 years ago and has been used as agricultural land in recent decades.

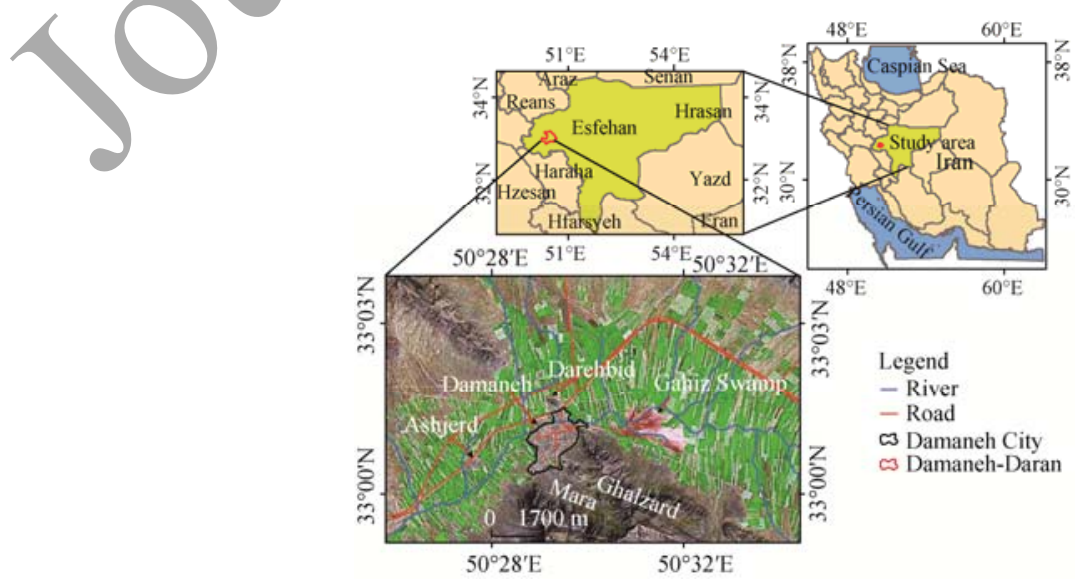

Fig. 1 Location of the study area 


\subsection{Geology}

Most of the study area is underlain by the Quaternary sediments that is underlain by the Jurassic shale. In the north part of the city, the Quaternary sediments can be over $100 \mathrm{~m}$ thick while the sediments in the south part is less than $10 \mathrm{~m}$.

\subsection{Hydrology}

Damaneh aquifer is a part of a larger unconfined aquifer with an area of $220 \mathrm{~km}^{2}$. It is composed of Quaternary alluvium which was transported from the southern and northern highlands and deposited on this vast plain (Fig. 2). The aquifer storage coefficient is about $2.8 \%$. The mean annual precipitation is about $343.5 \mathrm{~mm}$ and annual mean temperature is about $9.5^{\circ} \mathrm{C}$. The annual water withdrawal through the 800 wells is about $200 \times 10^{6} \mathrm{~m}^{3}$. About $97 \%$ of water withdrawal is used for agricultural irrigations.

According to the data from 16 piezometers in the study area, the average decline of groundwater head in recent years is over $1 \mathrm{~m} / \mathrm{a}$ and the decline can reach over $3 \mathrm{~m} / \mathrm{a}$ in dry years. The total decline of groundwater head is about $30 \mathrm{~m}$ from 1984 to 2012 .

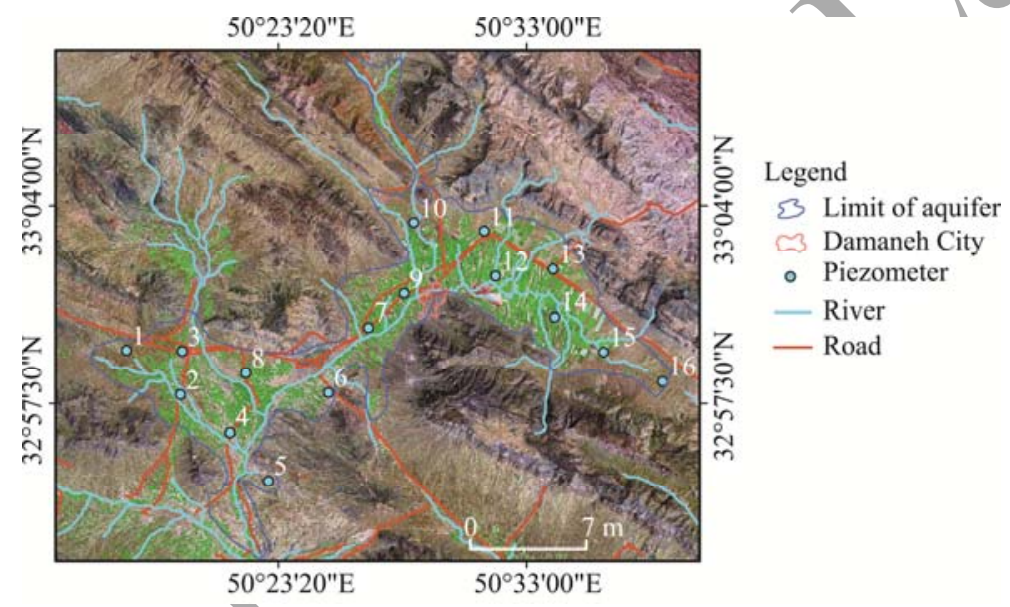

Fig. 2 Locations of Damaneh aquifer and piezometers in the study area

\section{Data and methods}

\subsection{Data}

For this research, data of location, trends and opening of fissures were obtained by field investigations. In order to determine the composition of the aquifer materials, 5 boreholes were drilled ( 40 m deep) within the city limit. Data of boreholes were obtained from the Department of Roads and Urban Development of Iran. The geophysical method was used to determine the composition, thickness, depth and shape of lower parts of the aquifer and bedrock topography. Data about fluctuations of groundwater table with 16 available piezometers during a 30 -year period were obtained from Isfahan Regional Water Company. The air photo was used to compare land use changes during the period 1955-2015). The radar interferometry technique was used to determine the rate and zone of subsidence. In this study, 8 ASAR images of 1.5 levels (unprocessed data) were used. The radar data from 457 and 250 tracks were evaluated. The ASAR-Envisat data were provided by the European Survey Agency (ESA) through CAT-1 C1P.10465.

\subsection{Methods}

The sizes and openings of fissures were measured by micrometer, the directions were measured by compass and the locations of about 45 fissures and wall cracks were determined by GPS. The borehole exploration permitted by the Department of Roads and Urban Development of Iran was to determine the type and thickness of sediments and the geoelectrical resistivity test was used to prepare the contour maps of sediment thicknesses and bedrock topography. With geoelectrical 
method, different sediment layers can be distinguished according to the specific electrical resistivity.

Piezometers data were spatially interpolated in GIS environment to study water table fluctuations. InSAR can derive information from the interferograms that are formed by phase differences between two high resolution SAR images for the same area (Saracin et al., 2014). The differential interferometric synthetic aperture radar (D-InSAR) is formed and the effect of topographic phase is calculated and removed (Raucoules et al., 2007; Liu et al., 2014) using digital elevation model and transforming elevation (motion) into phase. Radar data were processed by SARSCAPE in ENVI environment. In this method, interferometry with short time and spatial baseline were used (Lubis et al., 2011). The ASTER DEM (ASTER, Advanced Space borne Thermal Emission and Reflection Radiometer; DEM: Digital Elevation Model) with $30 \mathrm{~m}$ spatial resolution was used to remove topography phase. Goldstein filter was also used to remove noises and to strengthen radar signal. Minimum Cost Flow (MCF) was used in unwrapping phase. Interferograms were prepared from five radar data of 457 tracks (three interferograms) and three radar data of 250 tracks (three interferograms).

The locations of fissures, cracks and subsidence zones were designated and correlated with thickness of different sediment layers, bedrock topography and decline in groundwater head.

\section{Results}

\subsection{Field survey}

The results show that the locations of all fissures and cracks are in the northern city with east-west trends (Fig. 3a). Although the size of fissures opening varies, the biggest openings are observed in the northern and northeastern parts of the city at the positions with the lowest elevations (Fig. 3b).
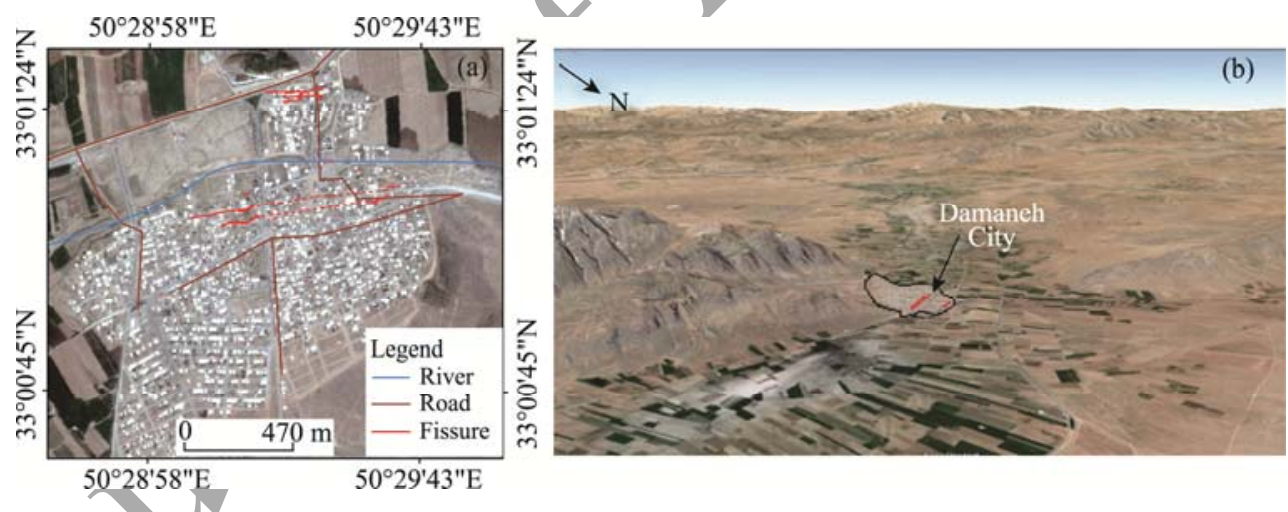

Fig. 3 Locations and trends of fissures in Damaneh City on Google Earth map (a), and geomorphology of the study area (b)

Except uplifted well casings, no fissure was detected at eastern Damaneh City. But damages to houses, power lines, gas pipes and water mains are rather visible in northern city (Fig. 4).
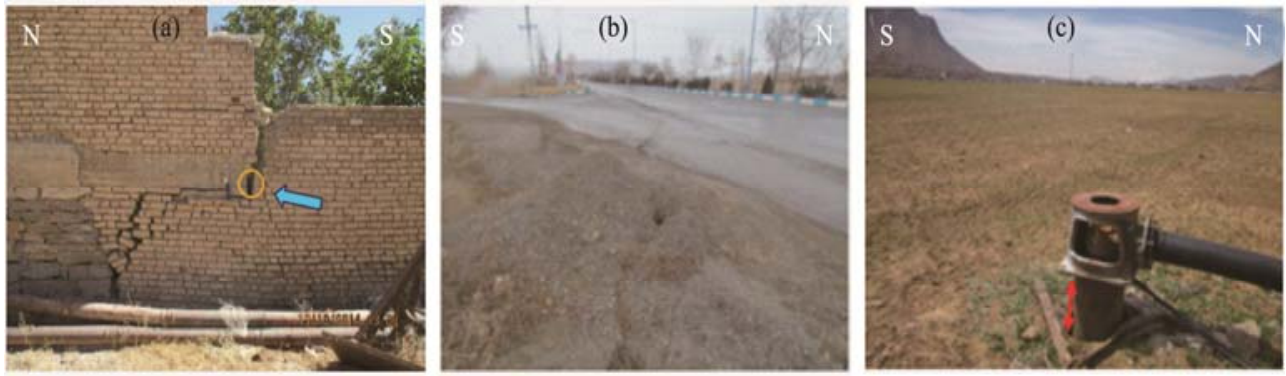

Fig. 4 Openings of wall cracks, $9.1 \mathrm{~cm}$ wide (a), road fissures (b), and uplifted well casing (c) 


\subsection{Air photo study}

For comparing the trend of land use changes, four air photos taken in 1955 were obtained and geo-referenced. The photos (Fig. 5a) were compared with Google Earth pictures taken in 2015 (Fig. 5b) using ArcGIS. As shown in Figure 5a, the residential areas and agricultural lands were very limited and the dark tone of Gahiz swamp shows that water table was rather high in the area. But, in Figure 5b, extensively developed residential areas and agricultural lands are radially observable. The city area expanded from 0.31 to $2.00 \mathrm{~km}^{2}$ during the period $1955-2015$.

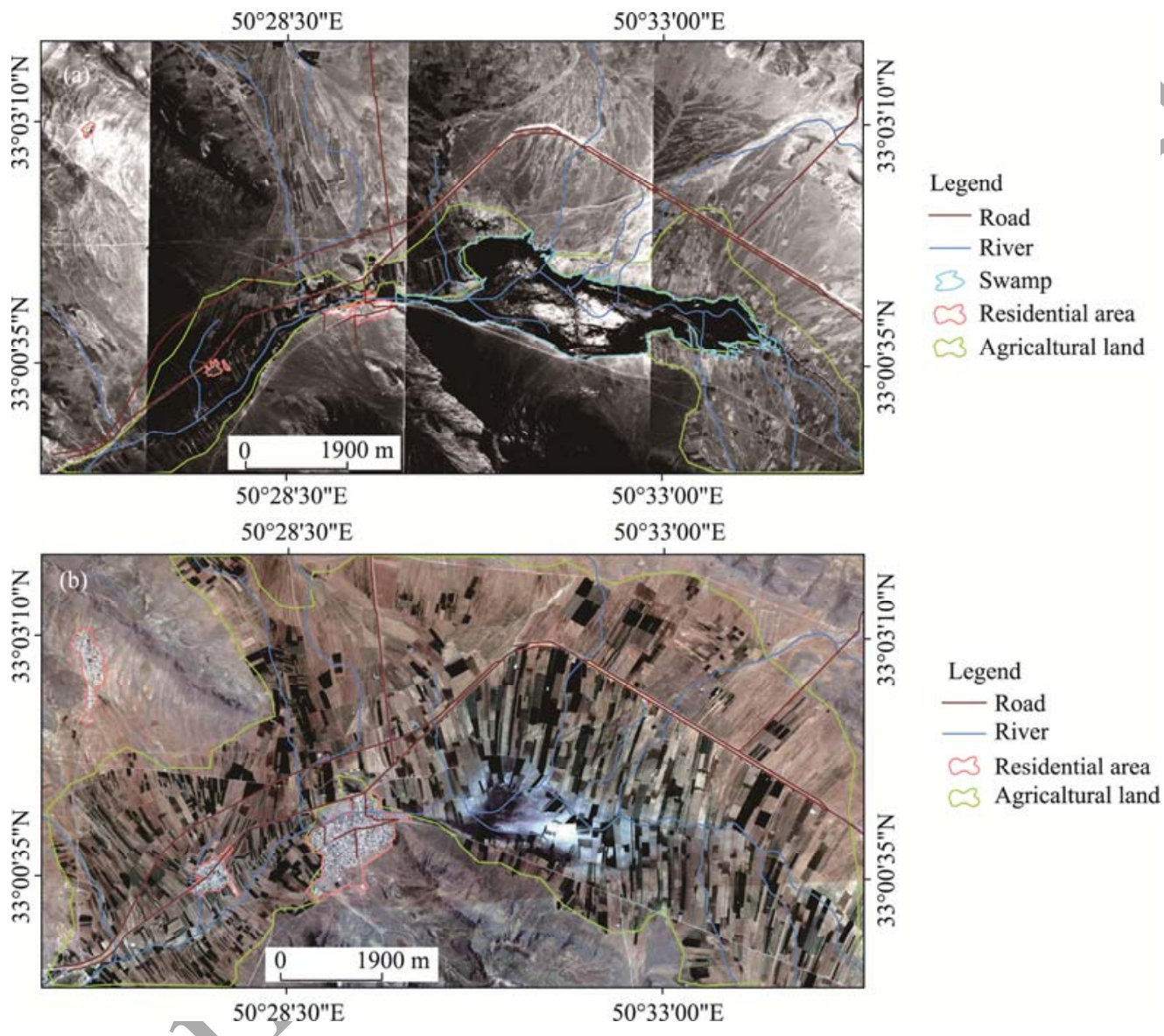

Fig. 5 Air photos taken in 1955 (a) and Google Earth pictures taken in 2015 (b)

Figure 6a shows that Damaneh City sits on highly compressible lacustrine sediments in 2015 and Figure $6 \mathrm{~b}$ shows that the situation of fissures in northern city is near the boundary of two different types of sediments in 1955 .
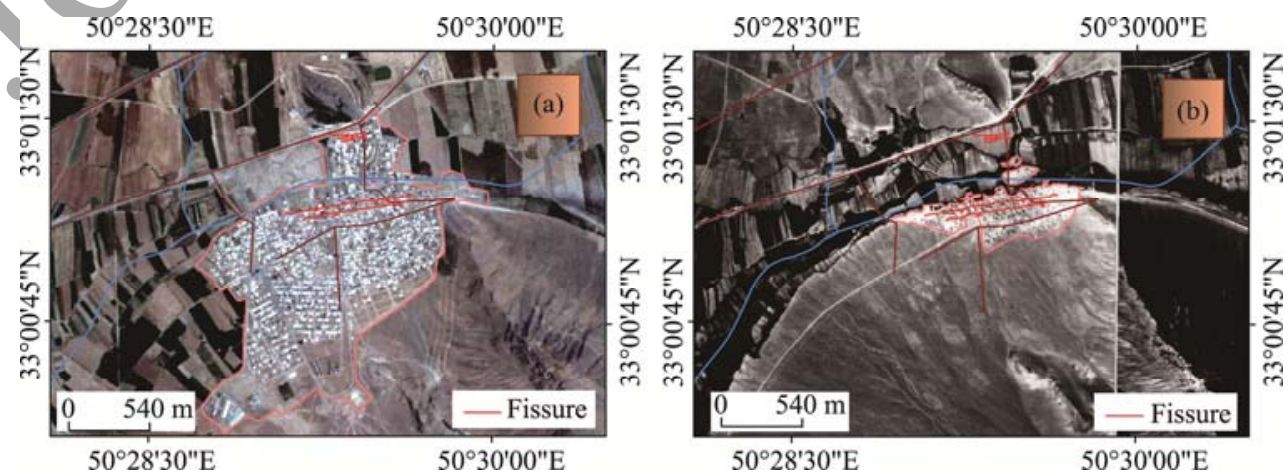

Fig. 6 Damaneh City on lacustrine sediments in 2015 (a) and fissure locations on border of sediment changes (b) 


\subsection{Evaluation of piezometer data}

In this study, the declines of groundwater head from March to December 2005 (Fig. 7a) and from January to July 2012 (Fig. 7b) were interpolated based on the data from 16 piezometers in the city. The highest declines of groundwater head in 2005 and 2012 were 2.13 and $7.14 \mathrm{~m}$ (Figs. 7a and $b$ ), respectively. This decline increases toward the western city where the area was dominated by coarser alluvium deposits. The sharp decline in groundwater head from 2005 to 2012 is mostly due to the increase in water withdrawal for agricultural irrigation.
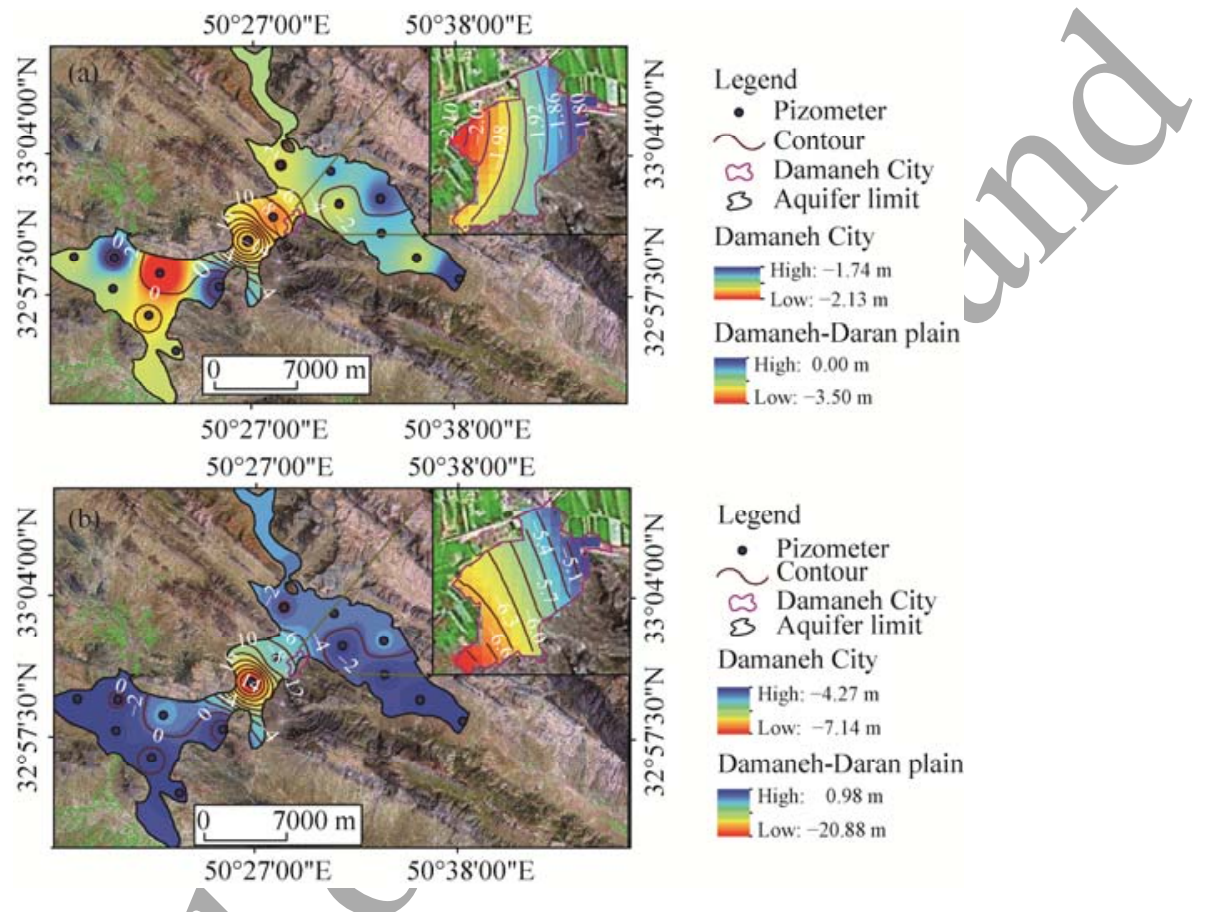

Legend

- Pizometer

$\frown$ Contour

3 Damaneh City

$\Xi$ Aquifer limit

Damaneh City

High: $-4.27 \mathrm{~m}$

Low: $-7.14 \mathrm{~m}$

Damaneh-Daran plain

High: $0.98 \mathrm{~m}$

Low: $-20.88 \mathrm{~m}$

Fig. 7 Decline of groundwater head from March to December 2005 (a) and from January to July 2012 (b)

\subsection{Borehole studies}

Subsidence features were observed in 5 boreholes drilled in the northern city (Fig. 8). Boreholes 1,4 and 5 were $30 \mathrm{~m}$ deep. Borehole 2 and 3 were 27 and $40 \mathrm{~m}$ deep, respectively. As shown in Figure 8, the sediments of boreholes 1, 2 and 3 were finer than those in boreholes 4 and 5 .

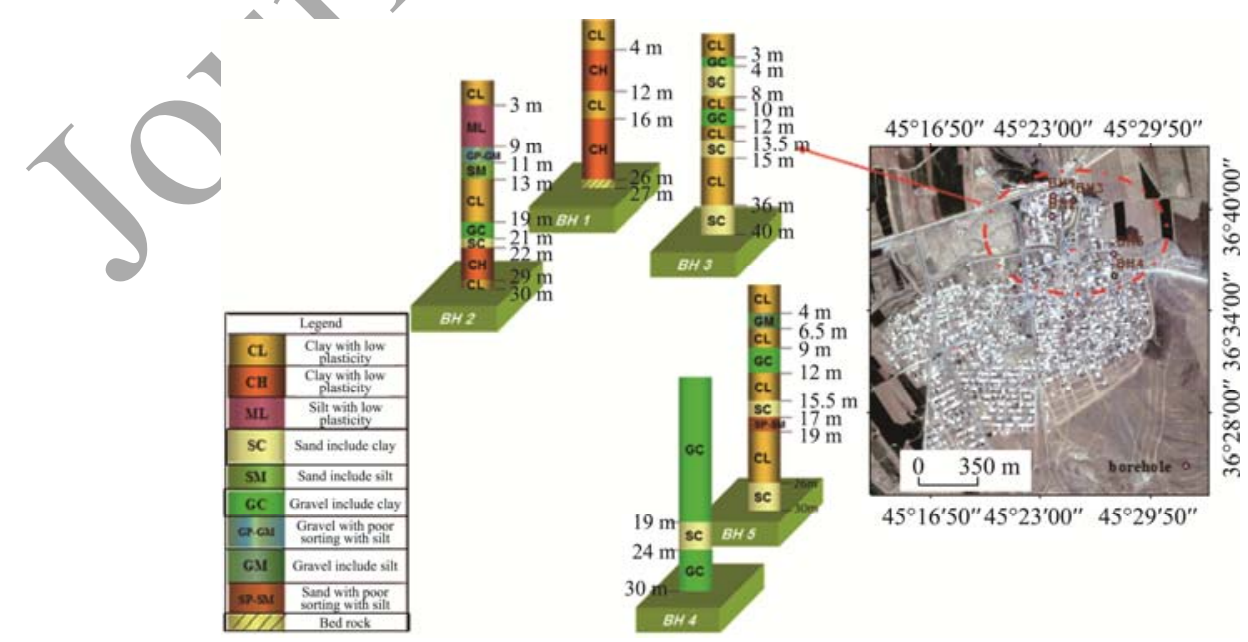

Fig. 8 Location of 5 boreholes drilled in the north part of the Damanech City 
According to the prepared profiles of the subsidence zones, the biggest subsidence occurred in the positions where finer sediments are present (boreholes 1, 2 and 3).

\subsection{Geophysical surveys}

The geoelectrical resistivity tests were conducted at 57 points along 8 profiles. The positions of the geophysical survey are shown in Figure 9. Two NW-SE profiles, one was from V1 to DC2 and and another one was from V1 to V14, were prepared, types, thicknesses and stratigraphy of the sediments along with the log data of these two profiles are shown in Figures 10a and b. Most of fissures are observed on the thickest layers with fine and compressible sediments.

The results of the interpolated geophysical data along with the changes of sediments thickness and the depth of bedrocks by ArcGIS are shown in Figures 11a and $\mathrm{b}$.

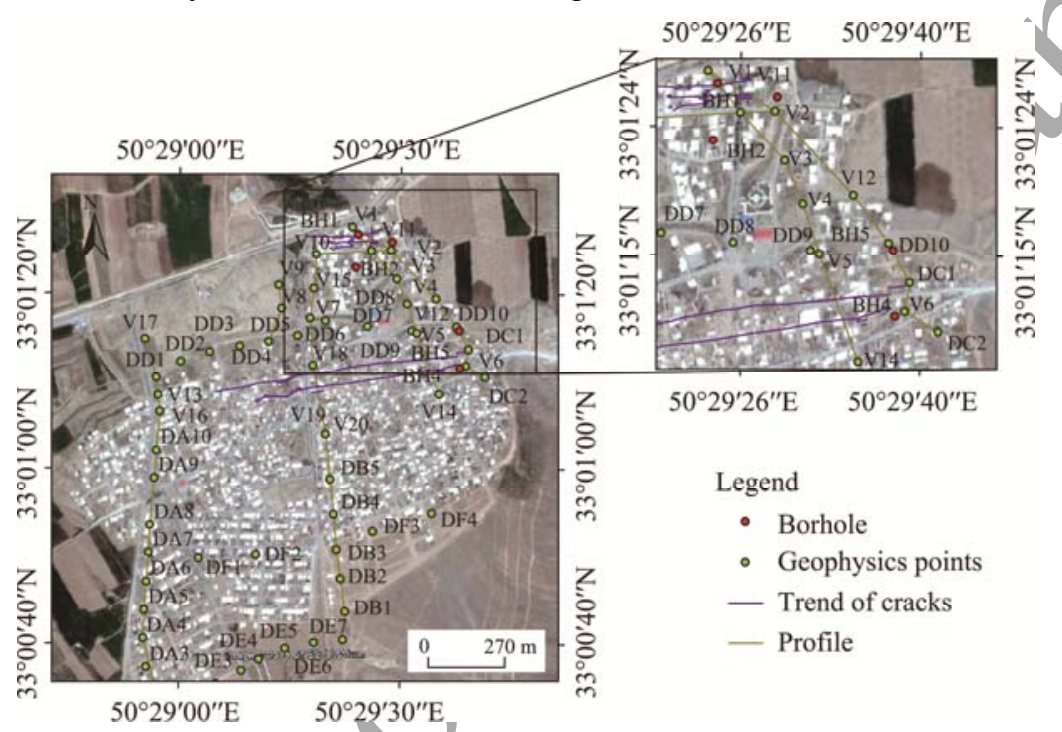

Fig. 9 Location of geophysical profiles and boreholes in the study area

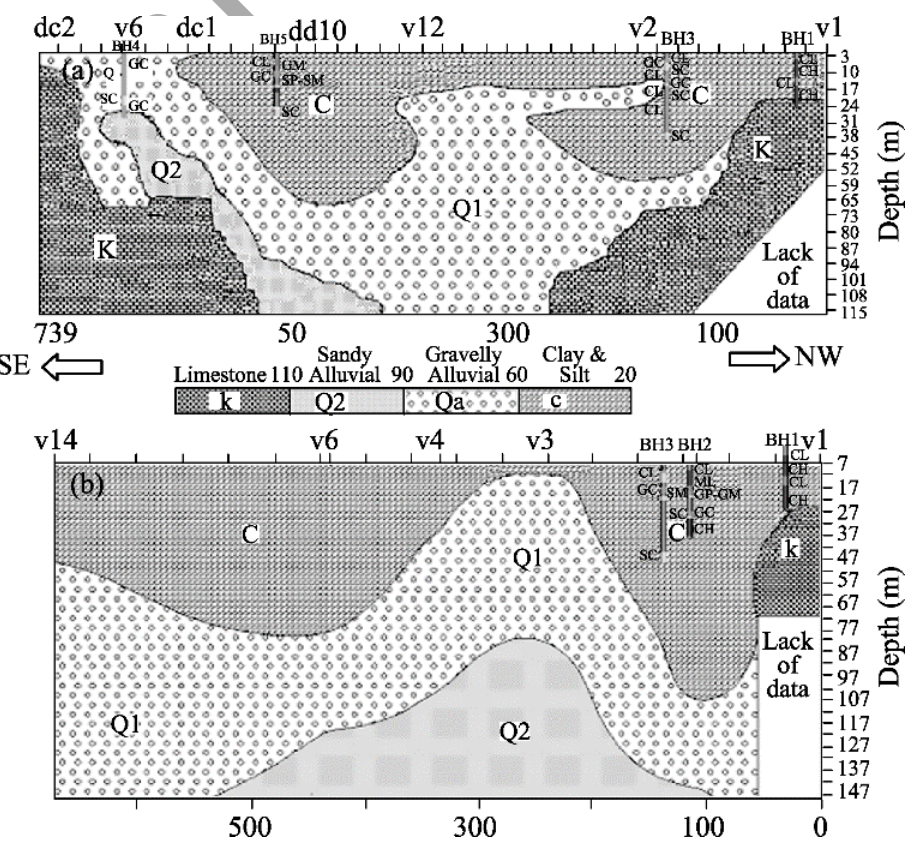

Fig. 10 Geophysical profiles, from V1 to DC2 (a) and V1 to V14 (b) 


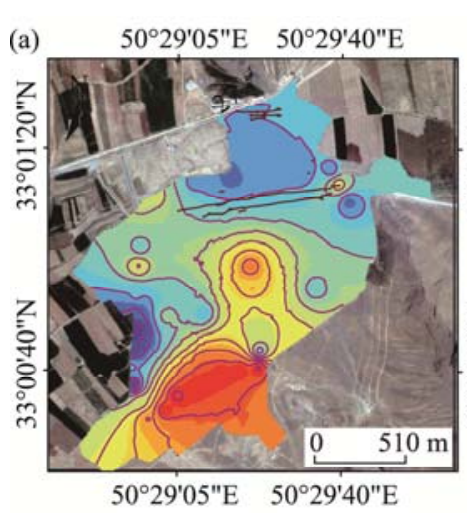

$0 \quad 510 \mathrm{~m}$

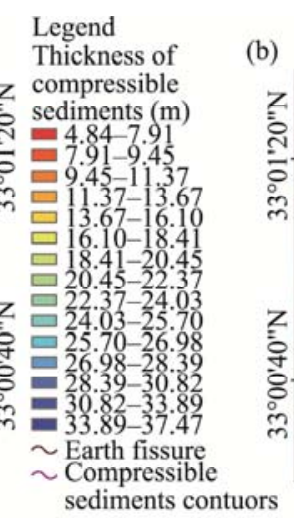

(b) $\quad 50^{\circ} 29^{\prime} 05^{\prime \prime} \mathrm{E} \quad 50^{\circ} 29^{\prime} 40^{\prime \prime} \mathrm{E}$
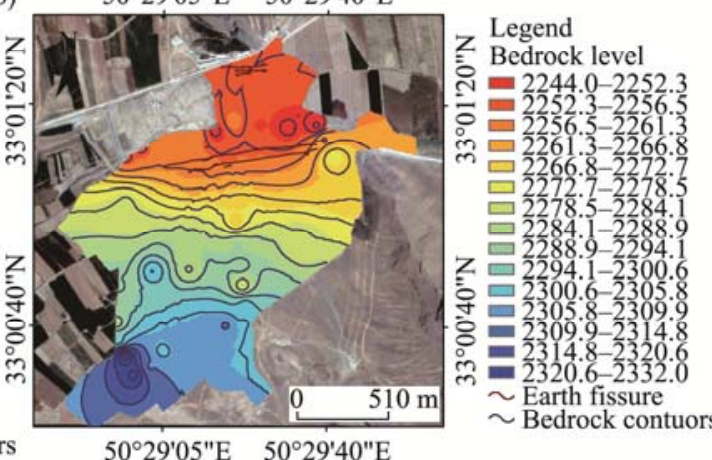

Fig. 11 Contour maps of fine sediment thicknesses (a) and bedrock topography (b)

\subsection{Evaluation of radar interferometry technique}

In this study, interferometry technique was also used to determine the zone and rate of subsidence. In this regard the band $\mathrm{C}$ of radar data from ASAR sensor of ENVISAT satellite related to 457 and 250 tracks were used. Table 1 shows the radar data used for differential interferometry and six interferograms used in this study and the parameters of created interferograms.

Table 1 Parameters of created interferogram

\begin{tabular}{|c|c|c|c|c|c|c|}
\hline Interferogram & Track & $\begin{array}{l}\text { Coherent } \\
\text { Average }\end{array}$ & $\begin{array}{c}\text { Maximum rate of land } \\
\text { subsidence }(\mathrm{m})\end{array}$ & $\begin{array}{l}\text { Normal Base- } \\
\text { line }(\mathrm{m})\end{array}$ & Sensor & Orbit type \\
\hline 29 Apr to $8 \mathrm{Jul}, 2005$ & 457 & 0.51 & -0.025 & 133.339 & ASAR & Ascending \\
\hline 25 Mar to 21 Oct, 2005 & 457 & & -0.055 & -258.404 & ASAR & Ascending \\
\hline 25 Mar to $30 \mathrm{Dec}, 2005$ & 457 & 0.40 & -0.067 & 910.759 & ASAR & Ascending \\
\hline $12 \mathrm{Jul}$ to $10 \mathrm{Sep}, 2011$ & 2. & 0. & -0.035 & 103.457 & ASAR & Descending \\
\hline 10 Sep, 2011 to 8 Jan, 2012 & 250 & 0.38 & -0.035 & -239.095 & ASAR & Descending \\
\hline $12 \mathrm{Jul}, 2011$ to $8 \mathrm{Jan}, 2012$ & & 0.36 & -0.070 & -315.959 & ASAR & Descending \\
\hline
\end{tabular}

The subsidence zone and the rate of subsidence for different period of time are shown in Figure 12. The subsidence zone is merely detectable in the north part of the city. The biggest subsidence rates were 6.7 and $7 \mathrm{~cm} / \mathrm{a}$ (Fig. 12f) for the period spanning from 25 March to 30 December, 2005 (Fig. 12c) and from 12 July, 2011 to 8 January, 2012, respectively. These two figures show that the locations of fissures are within the subsidence zone.

\subsection{Relationship between subsidence area and decline in ground water head}

The subsidence map obtained from interferogram studies and contour map of decline in groundwater head obtained from 16 piezometers were presented in Figure 13. The radar pictures from 25 March to 30 December, 2005 (Fig. 13a) and 12 July, 2011 to 8 January, 2012 (Fig. 13b) are well correspondent with the contour maps of decline in groundwater head.

\subsection{Relationships among subsidence, bedrock topography and sediment thickness}

A subsidence map from July 2011 to January 2012 was prepared and correlated with the contour maps of sediment thickness (Fig. 14a) and bedrock topography (Fig. 14b). Figure 14a shows that the thickness of fine sediments increased toward north where fissures obtained from radar processing and field measurements are intensively present. Map of bedrock topography also shows that the depth of bedrock increases toward north that is underlain by highly compressible fine sediments. 


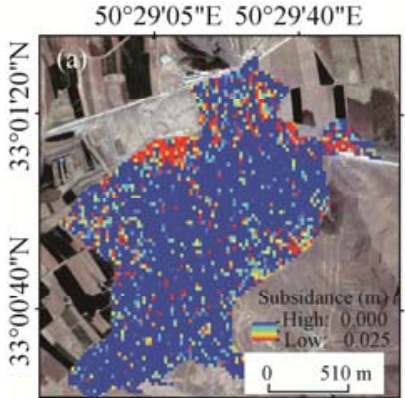

$50^{\circ} 29^{\prime} 05^{\prime \prime} \mathrm{E} 50^{\circ} 29^{\prime} 40^{\prime \prime} \mathrm{E}$ $50^{\circ} 29^{\prime} 05^{\prime \prime} \mathrm{E} 50^{\circ} 29^{\prime} 40^{\prime \prime} \mathrm{E}$

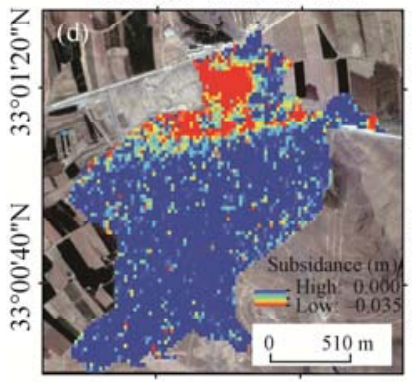

$50^{\circ} 29^{\prime} 05^{\prime \prime} \mathrm{E} 50^{\circ} 29^{\prime} 40^{\prime \prime} \mathrm{E}$ $50^{\circ} 29^{\prime} 05^{\prime \prime} \mathrm{E} 50^{\circ} 29^{\prime} 40^{\prime \prime} \mathrm{E}$

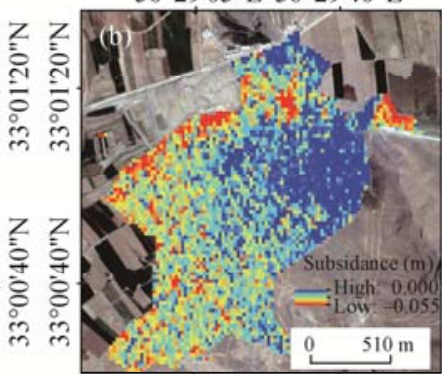

$50^{\circ} 29^{\prime} 05^{\prime \prime} \mathrm{E} 50^{\circ} 29^{\prime} 40^{\prime \prime} \mathrm{E}$

$50^{\circ} 29^{\prime} 05^{\prime \prime} \mathrm{E} 50^{\circ} 29^{\prime} 40^{\prime \prime} \mathrm{E}$

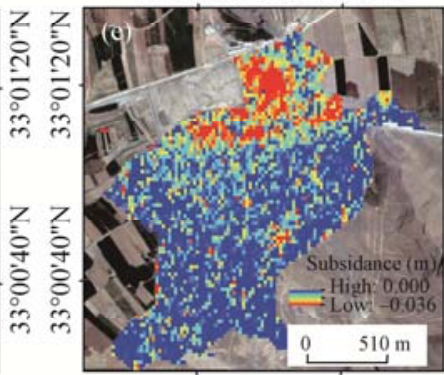

$50^{\circ} 29^{\prime} 05^{\prime \prime} \mathrm{E} 50^{\circ} 29^{\prime} 40^{\prime \prime} \mathrm{E}$

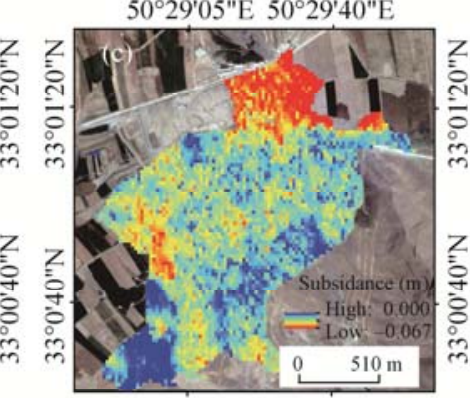

$50^{\circ} 29^{\prime} 05^{\prime \prime} \mathrm{E} 50^{\circ} 29^{\prime} 40^{\prime \prime} \mathrm{E}$ $50^{\circ} 29^{\prime} 05^{\prime \prime} \mathrm{E} 50^{\circ} 29^{\prime} 40^{\prime \prime} \mathrm{E}$

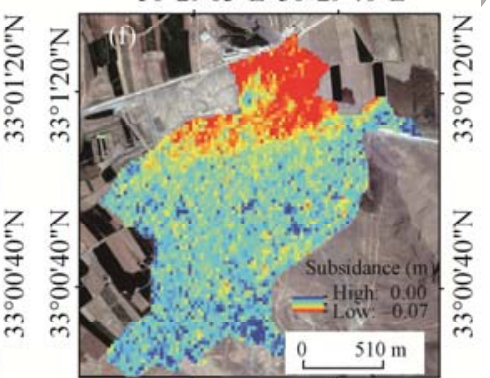

$50^{\circ} 29^{\prime} 05^{\prime \prime} \mathrm{E} 50^{\circ} 29^{\prime} 40^{\prime \prime} \mathrm{E}$

Fig. 12 Radar interferogram pictures for periods of 29 April to 8 July, 2005 (a), 25 March to 21 October, 2005 (b), 25 March to 30 December, 2005 (c), 12 July to 10 September, 2011 (d), 10 September, 2011 to 8 January, 2012 (e), and 12 July, 2011 to 8 January, 2012 (f)

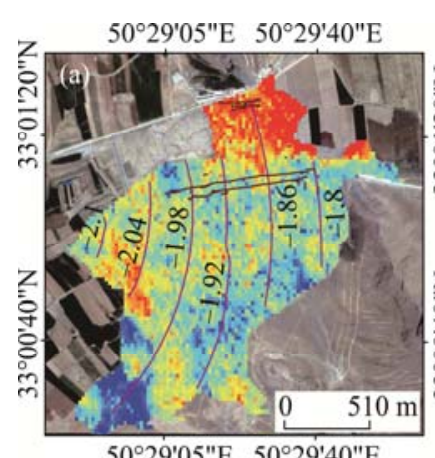

$50^{\circ} 29^{\prime} 05^{\prime \prime} \mathrm{E} \quad 50^{\circ} 29^{\prime} 40^{\prime \prime} \mathrm{E}$

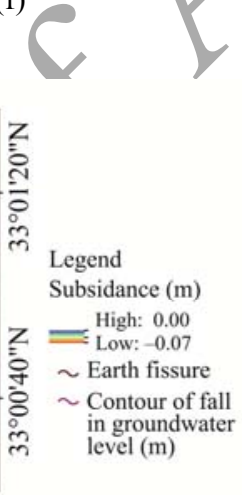

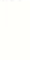

Fig. 13 Subsidence map obtained from radar interferometry along with contour map of decline in groundwater headduring periods of March to December 2005 (a) and July 2011 to January 2012 (b)

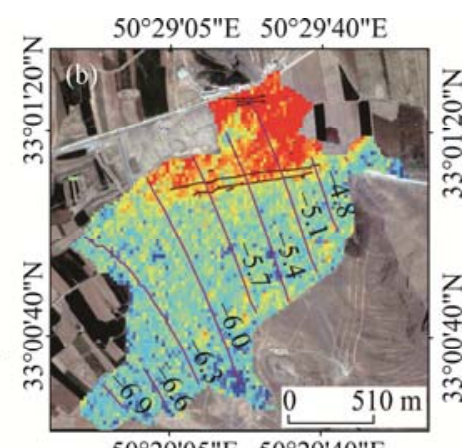

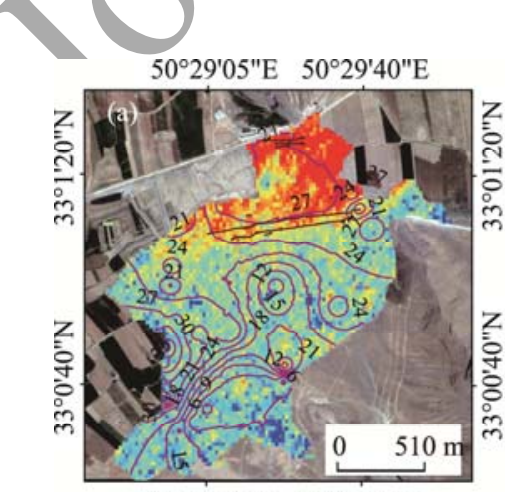

$50^{\circ} 29^{\prime} 05^{\prime \prime} \mathrm{E} \quad 50^{\circ} 29^{\prime} 40^{\prime \prime} \mathrm{E}$

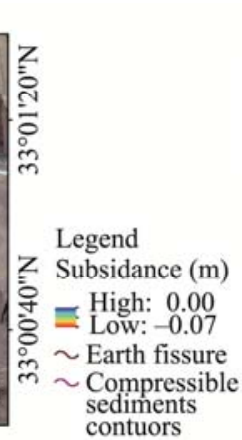

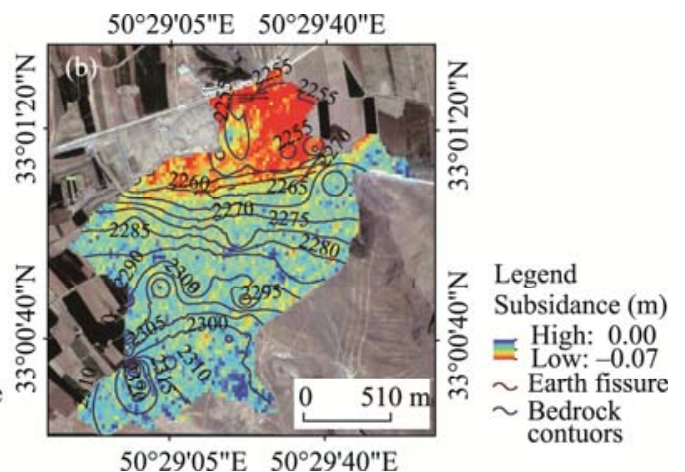

Fig. 14 Contour maps of sediment thickness (a) and bedrock topography (b) from July 2011 to January 2012 


\section{Discussion}

Ground subsidence and earth fissures have caused extensive damages to houses, infrastructures and roads in Damaneh City. The fissures in north part of the city are located on the sediments that used to be a swamp with soft clayey sediments and high water table. The results of this study show that groundwater withdrawal and associated decline in groundwater head have major effects on ground subsidence. The decline in groundwater head can result in reduction of pore water pressure and cause the effective stress to be increased and soil grains become more compacted (Burbey, 2002). Bonì et al. (2015) also found that the thickness of alluvial deposit has a direct relationship with the amount of subsidence in Guadalentin Basin of Spain. According to Helm (1994) and Bouwer (1977), various thicknesses of compressible soils can cause differential settlement and fissuring of ground surface. In this regard, differential settlement causes compaction at deeper layers and tension at shallower layers. As a result of differential settlement, the sediments tilt toward the areas with higher compaction. Adiyaman (2012) reported that the amount of subsidence is controlled by sediment type, thickness, stiffness, compressibility of soil and loading history. Adiyaman explained that the subsidence even at uniform decline rate of groundwater head will not be uniform due to the changes of soil type. The geophysical studies indicated that all of the fissures are observed in the north part of the city where the thickest layers of fine and compressible sediments with higher consolidation potential are present. The geophysical data also indicated that the presence of coarse-grain sediments in the southern part of city did not allow any consolidation and subsidence occurrences.

In recent years, interferometry is widely used to measure the deformation and displacement of the earth surface (Raucoules et al., 2007; Lubis et al., 2011; Bonì et al., 2015); and it is more attractive for displacement detection due to the high resolution of C-band SAR data (Lubis et al., 2011). In this study interferometry technique (ASAR images) was used to determine the zone and rate of subsidence. Bonì et al. (2015) reported that there is a clear relation between decline in groundwater head and the obtained subsidence map from interferometry images. The results of present study show that the subsidence zone is merely within northern part of the city and the highest subsidence rate ranges from 6.7 to $7.0 \mathrm{~cm} / \mathrm{a}$.

Comparison between the map of subsidence rate obtained from interferogram studies and the rate of decline in groundwater head obtained from 16 piezometers indicated that the maximum subsidence in the north part of city were correlated with the high decline in groundwater head. The locations of fissures can be detected along the border lines with thick and fine compressible sediments by correlating the contour maps of the sediment thickness with bedrock topography. This was also verified by radar results. These findings also agree with the studies conducted by Freyre et al. (2003) and Sheng et al. (2003). According to the studies conducted by Bonì et al. (2015), after developing a soil thickness map and estimating the subsidence rate from different available satellite data, the relationship between soil thickness and subsidence rates can be established.

\section{Conclusions}

Based on field investigations, piezometer data, geophysical survey, borehole studies, land use changes in the period 1955-2015 and radar interferometry technique, we concluded that the subsidence zone is located in the north part of Damaneh City and the major geological factor is the presence of very thick fine and compressible sediments. The amount of subsidence were 6.7 and $7 \mathrm{~cm}$ for the periods of March to December 2005 and July 2011 to January 2012, respectively. It can then be concluded that this phenomenon was caused by an increase in number of deep wells in the area (about 800 wells in and around the city), intense water withdrawal and decline in groundwater head. Therefore, the main cause of subsidence is not only due to the excessive groundwater pumping for intense agricultural activities but it is also due to housing development on thick and fine compressible sediments in the north part of the city. We suggested that groundwater withdrawal from the thick fine sediments should be restricted and the urban 
expansion in the northern direction should be constrained to prevent further damages to the city.

\section{Acknowledgments}

This research was conducted in department of geology at the University of Isfahan. The authors would like to thank the European Space Agency (ESA) for providing SAR images (ENVISAT data).

\section{References}

Adiyaman I B. 2012. Land subsidence and earth fissures due to groundwater pumping. PhD Dissertation. Tucson: University of Arizona.

Bates R L, Jackson J A. 1980. Glossary of Geology (2 ${ }^{\text {nd }}$ ed.). Falls Church, Virginia: American Geological Institute, 749.

Bell F G. 1999. Geological Hazards: Their Assessment, Avoidance and Mitigation. London: E and FN Spon.

Bell J W, Price J G. 1991. Subsidence in Las Vegas Valley, 1980-91-final project report. Reno: Nevada Bureau of Mines and Geology.

Bell J W, Amelung F, Ramelli A R, et al. 2002. Land subsidence in Las Vegas, Nevada, 1935-2000: new geodetic data show evolution, revised spatial patterns, and reduced rates. Environmental and Engineering Geoscience, 8(3); $155-174$.

Bonì R, Herrera G, Meisina C, et al. 2015. Twenty-year advanced DInSAR analysis of severe land subsidence: the Alto Guadalentín Basin (Spain) case study. Engineering Geology, 198: 40-52.

Bouwer H. 1977. Land subsidence and cracking due to ground-water depletion. Ground Water, 15(5): 358-364.

Burbey T J. 2002. The influence of faults in basin-fill deposits on land subsidence, Las Vegas Valley, Nevada, USA. Hydrogeology Journal, 10(5): 525-538.

Carruth R L, Pool D R, Anderson C E. 2007. Land subsidence and aquifer-system compaction in the Tucson Active Management Area, south-central Arizona, 1987-2005. Reston, Va.: U.S. Department of the Interior, U.S. Geological Survey, 27.

Chatterjee R S, Fruneau B, Rudant J P, et al. 2006. Subsidence of Kolkata (Calcutta) City, India during the 1990s as observed from space by Differential Synthetic Aperture Radar Interferometry (D-InSAR) technique. Remote Sensing of Environment, 102(1-2): 176-185.

Esmaili M, Motagh M. 2009. Remote sensing measurements of land subsidence in Kerman valley, Iran, 2003-2009. In: American Geophysical Union, Fall Meeting 2009, Abstract, NH43C-1348.

Freyre D C, Cerca M, Marin M H. 2003. Propagation of fracturing related to land subsidence in the valley of Queretaro, Mexico. In: Multidisciplinary Studies of Land Subsidence and Regional Fracturing in Fluvio-Lacustrin Basons. Puerto Vallarta, Mexico, 2.

Galloway D L, Ingebritsen S E, Riley F S, et al. 1999. The role of science. In: Galloway D L, Jones D R, Ingebritsen S E. Land Subsidence in the United States: U.S. Geological Survey Circular. [S.1.]: U.S. Geological Survey, 1182: 141-158.

Galloway D L, Jones D R, Ingebristen S E. 2000. Ground water resources for the future US U.S. Geological Survey Fact Sheet-165-, 4.

Galloway D L, Hoffmann J.2007. The application of satellite differential SAR interferometry-derived ground displacements in hydrogeology. Hydrogeology Journal, 15(1): 133-154.

Galloway D L, Burbey T J. 2011. Review: regional land subsidence accompanying groundwater extraction. Hydrogeology Journal, 19(8): 1459-1486.

Ghazifard A, Moslehi A, Safaei H, et al. 2016. Effects of groundwater withdrawal on land subsidence in Kashan Plain, Iran. Bulletin of Engineering Geology and the Environment, 75(3): 1157-1168, doi: 10.1007/s10064-016-0885-3.

Helm D C. 1994. Hydraulic forces that play a role in generating fissures at depth. Bulletin Association Engineering Geologists, 31(3): 293-304.

Hoffmann J, Zebker H A, Galloway D L, et al. 2001. Seasonal subsidence and rebound in Las Vegas Valley, Nevada, observed by synthetic aperture radar interferometry. Water Resources Research, 37(6): 1551-1566.

Holzer T L, Galloway D L. 2005. Impacts of land subsidence caused by withdrawal of underground fluids in the United States. Geological Society of America: Reviews in Engineering Geology, 16(303): 87-99.

Hou C S, Hu J C, Shen L C, et al. 2005. Estimation of subsidence using GPS measurements, and related hazard: the Pingtung Plain, southwestern Taiwan. Comptes Rendus Geoscience, 337(13): 1184-1193.

Liu D L, Shao Y F, Liu Z G, et al. 2014. Evaluation of InSAR and TomoSAR for monitoring deformations caused by mining in a mountainous area with high resolution satellite-based SAR. Remote Sensing, 6(2): 1476-1495. 
Lubis A M, Sato T, Tomiyama N, et al. 2011. Ground subsidence in Semarang-Indonesia investigated by ALOS-PALSAR satellite SAR interferometry. Journal of Asian Earth Sciences, 40(5): 1079-1088.

Massonnet D, Feigl K L. 1998. Radar interferometry and its application to changes in the earth surface. Reviews of Geophysics, 36(4): 441-500.

Ortega-Guerrero A, Rudolph D L, Cherry J A. 1999. The analysis of long-term land subsidence near Mexico City: field investigations and predictive modeling. Water Resources Research, 35(11): 3327-3341.

Phien-Wej N, Giao P H, Nutalaya P. 2006. Land subsidence in Bangkok, Thailand. Engineering Geology, 82(4): 187-201.

Pope J P, Burbey T J. 2004. Multiple-aquifer characterization from single borehole extensometer records. Ground Water, 42(1): $45-58$.

Raucoules D, Colesanti C, Carnec C. 2007. Use of SAR interferometry for detecting and assessing ground subsidence. Comptes Rendus Geoscience, 339(5): 289-302.

Rosen P A, Hensley S, Peltzer G, et al. 2004. Updated repeat orbit interferometry package released. EOS, Transactions American Geophysical Union, 85(5): 47.

Saracin A, Cosarca C, Didulescu C, et al. 2014. Using InSAR technology for monitoring vertical deformation of the earth surface. Advances in environmental development, geomatics engineering and tourism. In:Proceedings of the 2nd European Conference of Geodesy and Geomatics Engineering (GENG 14). Brasov, Romania: GENG, 41-48.

Sharifikia M. 2009. D-InSAR data processing and analysis for mapping land subsidence phenomenon in Rafsanjan area. Thesis. Submitted to Andra University-India.

Sheng Z P, Helm D C, Li J. 2003. Mechanisms of earth fissuring caused by groundwater withdrawal. Environmental and Engineering Geoscience, 9(4): 351-362.

Sneed M, Galloway D L. 2000. Aquifer-system compaction and land subsidence: measurements, analyses, and simulations-the Holly Site, Edwards Air Force Base, Antelope Valley, California. USGS.

Wang G Y, You G, Shi B, et al. 2009. Long-term land subsidence and strata compression in Changzhou, China. Engineering Geology, 104(1-2): 109-118.

Wei Q L. 2006. Land subsidence and water management in Shanghai. MSc Thesis. Delft: Delft University. 